\title{
ACADEMIC MOBILITY AND THE EXPERIENCES OF FOREIGN STAFF AT SOUTH AFRICAN HIGHER EDUCATION INSTITUTIONS
}

\author{
C. Sehoole* \\ Dean: Faculty of Education \\ e-mail: chika.sehoole@up.ac.za
}

\author{
K. S. Adeyemo* \\ Department of Education Management and Policy Studies \\ e-mail: samuel.adeyemo@up.ac.za

\section{E. Ojo} \\ School of Education, Faculty of Humanities \\ University of the Witwatersrand \\ Johannesburg, South Africa \\ e-mail: Emmanuel.Ojo@wits.ac.za

\section{R. Phatlane*} \\ Office of the Dean \\ Faculty of Education \\ e-mail: Rakgadi.Phatlane@up.ac.za \\ *University of Pretoria \\ Groenkloof Campus \\ Pretoria, South Africa
}

\section{ABSTRACT}

This article analyses patterns of international academic mobility and the experiences of foreign staff at South African higher education institutions. Using the "pull and push factors" as a conceptual framework, it argues that the patterns of international academic staff mobility follow the pattern of international cross-border migrants. These are driven mainly by the pull factors which include quest for better opportunities in life including education. This study used both quantitative and qualitative methods to uncover the motivations and experiences of foreign academics in South Africa. The article uses three sources of data namely documentary analysis, statistical data from the Department of Education's Higher Education Management Information System (HEMIS), and data from questionnaires that were distributed to foreign academic staff at the three South African universities; namely, the University of Pretoria, University of South Africa, and University of the Witwatersrand. For the foreign academic staff working in South Africa, it was demonstrated that they have both positive and negative experiences. The negative experiences seem to be related to the major nation building project to overcome racism and xenophobia. The principles of non-racialism and, non-discrimination need to be promoted in order to build an inclusive and socially coherent society.

Keywords: academic mobility, internationalisation, migration, push factors, pull factors. 


\section{INTRODUCTION}

South African higher education has suffered from academic and cultural boycotts as a result of the apartheid system that was in place before 1994. With the demise of apartheid in 1994 and South Africa's embracing of globalization policies in the mid-1990s, the country became a destination of choice especially for African scholars and students who wanted to pursue their careers and further their studies. In 2008 for example, South Africa was ranked as the $8^{\text {th }}$ popular destination for international students worldwide (Institute of International Education 2011). There are a number of studies (MacGregor 2007; Butcher et al. 2008; Sehoole 2008; Sehoole 2011) that have been conducted on international student mobility in South Africa; but not much has been done on the mobility and experiences of academic staff.

This article explores the number of foreign academic staff found in South African higher education institutions between the years 2000 and 2010, the world regions they came from and the gender dimensions of this academic staff. It further provides a snapshot analysis of the rationales for their choice of South Africa as their destination together with the experiences of their access into the South African labour market. The article foregrounds the patterns of international academic mobility in order to locate South African academic mobility in a global context. In this regard, emergent themes include the use of foreign academic staff in nation building (Japan and former British, Spanish, French and Portuguese colonies), in the establishment of national universities and how xenophobia in Nazi Germany served as a push factor to drive foreign academic staff out of the German higher education system. Foreign academic staff had been used in building capacity and expertise in higher education system in Japan, it was withdrawn by the Japanese in favour of the employment of Japanese nationals.

This article further draws a relationship between staff mobility and student mobility as the latter is used by some countries as a recruitment base for skilled labour. Literature shows that only one out of every three students who travel abroad for studies returns to Africa (Okereke 2012), implying that mobile students are a fertile ground for the recruitment of foreign labour and expertise once they complete their studies. The study of mobility in this article is done in the context of the broader study of the migration phenomenon as the two are intractably linked. The phenomena of mobility and migration give rise to two other phenomena namely brain drain and brain gain depending on their impact on countries involved. The migration of skilled professionals from a "mostly poorer" country into another considered as "mostly richer" for economic reasons in other to engage in work is considered as brain drain (Benedict and Ukpere 2012). On the other hand, Meyer (1996) delineates the concept of brain gain as referring to aspects of the migration of professionals to and from a country which include a way of 
developing knowledge and human resources in a national community, through the use of its expatriate citizen abroad. The central purpose of this study is the critical exploration of foreign academic experiences. Academics' motivations for place of work can vary widely, depending on their country of origin, and the same is true for their experiences upon arrival. Research that takes a critical perspective on these issues is especially limited.

\section{METHODOLOGY}

Data used in this article are mainly from documentary analysis (literature review and other mobility documents). Academic Staff Mobility in South Africa higher education questionnaires and statistical data from Department of Education's Higher Education Management Information System (HEMIS), which has built a national database from information obtained from institutions. The questionnaires were administered randomly to instruction and research (or academic) staff (permanent and contract/non-permanent staff) of three South African universities: the University of South Africa (UNISA), University of the Witwatersrand (Wits) and the University of Pretoria (UP). The gender representation of the respondents $(n=8)$ is 87.5 per cent male and 12.5 per cent female. All the respondents had Masters degrees and $\mathrm{PhD}$ in equal proportion (50 per cent Masters Degrees while the other 50 per cent have $\mathrm{PhDs}$ ). The average age of the respondents was 35 years. Since the focus of the article is on academic staff mobility amongst Africans coming to South Africa universities, statistical data from the DHET extracted only data on Africans. The table below gives a description of the sample:

\begin{tabular}{|c|c|c|c|c|c|c|c|}
\hline $\begin{array}{l}\text { Position } \\
\text { at } \\
\text { institution }\end{array}$ & $\begin{array}{c}\text { Highest } \\
\text { Qualification }\end{array}$ & $\begin{array}{c}\text { Institution } \\
\text { where } \\
\text { qualification } \\
\text { was received }\end{array}$ & $\begin{array}{l}\text { Country } \\
\text { of Birth }\end{array}$ & Age & Gender & $\begin{array}{c}\text { Role at } \\
\text { Institution }\end{array}$ & $\begin{array}{l}\text { Length of } \\
\text { time in } \\
\text { South } \\
\text { Africa } \\
\end{array}$ \\
\hline Lecturer & $\begin{array}{l}\text { PhD } \\
\text { Educational } \\
\text { Studies }\end{array}$ & $\begin{array}{l}\text { University of } \\
\text { Western } \\
\text { Ontario } \\
\text { Canada }\end{array}$ & Zimbabwe & 43 & Male & $\begin{array}{l}\text { Lecturer on } \\
\text { Probation }\end{array}$ & 4 months \\
\hline $\begin{array}{l}\text { Senior } \\
\text { Tutor }\end{array}$ & M Ed & $\begin{array}{l}\text { University of } \\
\text { Zimbabwe }\end{array}$ & Zimbabwe & 51 & Male & Tutoring & 4 years \\
\hline Lecturer & $\begin{array}{l}\text { MSc; } \\
\text { Mathematics } \\
\text { Education }\end{array}$ & $\begin{array}{l}\text { Witwatersrand } \\
\text { University }\end{array}$ & Nigeria & 37 & Male & $\begin{array}{l}\text { Lecturing, Co- } \\
\text { ordinating of } \\
\text { Maths PGCE } \\
\text { Programme etc }\end{array}$ & 9 years \\
\hline $\begin{array}{l}\text { Senior } \\
\text { Tutor }\end{array}$ & $\begin{array}{l}\text { MA in Drama } \\
\text { Education }\end{array}$ & Wits & Botswana & 37 & Male & Tutoring & $\begin{array}{l}4 \text { years } \\
\text { five } \\
\text { months }\end{array}$ \\
\hline Lecturer & $\mathrm{PhD}$ & South Africa & Malawi & 42 & Male & Lecturing & 9 years \\
\hline $\begin{array}{l}\text { Senior } \\
\text { Lecturer }\end{array}$ & $\begin{array}{l}\text { PhD Real } \\
\text { Estate }\end{array}$ & $\begin{array}{l}\text { KTH } \\
\text { Stockholm }\end{array}$ & Ghana & 45 & Male & $\begin{array}{l}\text { Director: Real } \\
\text { Estate } \\
\text { Programme }\end{array}$ & $\begin{array}{l}\text { Less than } \\
1 \text { year }\end{array}$ \\
\hline Lecturer & $\mathrm{PhD}$ & $\begin{array}{l}\text { University of } \\
\text { Pretoria }\end{array}$ & Kenya & 51 & Female & $\begin{array}{l}\text { Lecturing and } \\
\text { Programme co- } \\
\text { ordinator }\end{array}$ & 18 years \\
\hline Lecturer & $\begin{array}{l}\text { Med } \\
\text { Psychology }\end{array}$ & $\begin{array}{l}\text { Unisersidad } \\
\text { Veracruzana: } \\
\text { Mexico }\end{array}$ & Lesotho & 48 & Male & Lecturer & 5 \\
\hline
\end{tabular}


African academics within the context of this article has been defined as permanent and contract or non-permanent staff. Each academic spends at least fifty per cent of the official work time on teaching and research. This is about the same trend even with other academic staff who have permanent residence or have naturalised as a South African citizen.

The questionnaire explored the following aspects of international academic staff in South Africa,

- Reasons academics chose to work in South Africa;

- $\quad$ Reasons for choice of institution;

- Treatment within the institutions in terms of academic upward mobility and socially general associations; and

- Experiences of processes within the country's Home Affairs Department, within the country in general and within their institutions in particular

\section{REVIEW OF LITERATURE AND CONCEPTUAL FRAMEWORK}

Most existing studies have focused on foreign academics and international students" "inability" to successfully "integrate" into the host organization; few studies examine ways that the university and local community may contribute to the very barriers that make adjustment difficult for these migrants (Lee and Cantwell 2012; Marginson et al. 2010). Past research studies have tended to assume that foreign academics' experiences are generally uniform, ignoring reasons why some groups might experience greater difficulties than others. One of major contributions to the international higher education literature has been to document foreign academics' uneven experiences and to apply neo-racism theory to explain reported acts of discrimination and hostility against them (Lee and Rice 2007; Lee and Opio 2011). Whereas racism is traditionally based on one's phenotype and stereotypes associated with a certain race, neo-racism extends the concept to include stereotypes about one's country of origin. The basis of neo-racism is an attempt to assert the superiority of particular cultures and national orders and to maintain racial hierarchies of oppression (Balibar 1991; Hervik 2004). Thus, people marginalize particular groups in the globalizing world in an attempt to preserve their own national identity. There has been research that documented that African, Asian, and Latin American academics and students in the US face discrimination that far surpasses the challenges faced by academics and students from western nations, including Europeans, Canadians, and Australians.

There is currently a higher number of persons living and working outside their country of 
birth than what it was previously, with a significant increment in the number of women migrants (Martin 2004). More people are migrating today than at any other point in human history. Part of the explanation for this is the role of globalization, which has blurred historical barriers to mobility and allowed for advances in information and communication technology. This has resulted in greater disparity amongst countries in terms of salaries, employment opportunities and living conditions. Franzoni, Scellato and Stephan (2012) highlighted the fact that scientists are among the most highly mobile groups. As an example, Barjak (2005) claimed that, the study of postdoctoral researchers working in Europe in Life Sciences found that 43 per cent were working in a country other than that of their birth. The same trend is identifiable in the United States where 41.6 per cent of those with a PhD working in the field of Science and Engineering in 2009 were born outside of the United States (National Science Board 2012).

In their study of the phenomenon of international student circulation, Agarwal et al. (2007) developed the pull and push framework to understand key features which may play a role in the student's mobility by country/region from a comparative standpoint. Two features were identifiable: "outward mobility" and "inward mobility". Outward mobility is synonymous with push factors and explains the reasoning behind students studying abroad for their degree. The pull factors, on the other hand, are those factors that attract students to choose to study for a degree in the particular country (inward bound). The pull-push framework will be used in this study to identify what pushes faculty out and what pulls faculty into a specific country for work purposes. Against this background, the next session will review relevant literature to present the historical perspective of academic mobility and experiences of foreign staff within the global, regional and national contexts.

\section{EXPERIENCES AND PATTERNS OF ACADEMIC MOBILITY IN HIGHER EDUCATION}

The paybacks and shortcomings of international study have been well established. International study has been touted as a significant contributor to the host country's economic and intellectual capital, preparing global citizens, and strengthening international diplomacy (Altbach 1989; Lee and Rice 2007). On the downside, foreign academics experience difficulties with social integration (Sawir et al. 2008), problems in cultural adaptation (Heggins and Jackson 2003), and cultural differences in perceptions of time and gender roles (Pritchard and Skinner 2002). There is an emerging and significant body of knowledge that foregrounds this article. This examines and distinguishes migration from the perspective of the global South (Cantwell, Luca, and Lee 2009; Kondakci 2011; Sehoole 2011).

The political ideology in Germany became more important than the advancement of 
knowledge during the inter-war period (1918-1938). The Nazi German era experienced a specific pattern of knowledge transfer and academic mobility where the Nazi regime began mass dismissals of scientists, judges and other scholars of Jewish origin. This resulted in Germany during these years losing its best pool of scientists and scholars to the United States and United Kingdom. As argued by Kim (2009), the development of this era evolved into the move of advanced form of transnational mobility of scholars and knowledge. In addition to this, international centres of excellence became redefined during this period (Kim 2009). As it is, racial discrimination (or xenophobia) became the push factor that drove scientists out of Germany. This trend brought about the advent of academic mobility after the Second World War. The United States became the destination of choice for highly skilled labour, including scientists and engineers, from the rest of the world. This historical antecedent shaped the "brain drain" and "brain gain" debates, and led to the coined phrase "brain drain" created by the British Royal Society in 1963. The 1950s, as an example, saw a significant outflow of skilled from Europe (United Kingdom) to North America (United States and Canada), with the United States permanently attracting about seven percent of the doctorates produced in science and engineering.

The post-world war developments did not only affect Europe, but colonies in the African continent were also affected. With the decolonization movement that started with Ghana as the first African country to be granted independence, African higher education, which until then was under-developed, started to experience some form of mobility which until then had been minimal. The one form of mobility was induced by the establishment of Universities in newly independent African countries which were started as university colleges of major universities in metropole countries. For example, at independence in 1957, the University of Gold Coast had a special affiliation with the University of London. The University of London awarded its degrees until 1961. Similarly, Tanzania at independence in 1961, established the University of Dar Es Salaam as a college of the University of London (Ishengoma 2008). Even though it only attained its independence only in 1975, Mozambique had as early as 1962, established Estudoseraris University as a branch of a Portuguese university (Mario et al. 2003). The common trend and practice in these developments is that all these universities relied on expatriate staff for their establishment and operations. Like in the case of Brazil, professors were recruited from the metropole centres to teach in these universities. These institutions also adopted the languages of the metropoles as the lingua franca. Academic mobility in this context was mainly driven by national service and a sense of exploration as some of the academics were seconded by their governments and institutions to come work in the colonies.

The expansion in the number of many universities in many African nations resulted in the 
building of capacity in human resources and skills in important service areas such as health and education. The locally trained personnel complemented expatriate civil service and academics that were working in different government services and the universities. However, the building of capacity and expertise in universities and other government services was undermined by the imposition of ill-conceived International Monetary Fund (IMF) mandated structural adjustments articulated and enforced by the World Bank. This policy redirected educational priorities toward primary education (the "education for all" policy) to the successive disregard of higher education (Zeleza 2003; Samoff and Carrol 2004; Sehoole 2008). Combined with the repressive regimes that took over power in some African countries, a spate of exodus (outward mobility) of professionals and university professors started with many of them leaving for countries in the North. The table below provides estimates of skilled Africans that immigrated to Industrialised Countries over a period of time.

Table 1: Emigration of Skilled Africans to Industrialised Countries (based on IOM and ECA estimates)

\begin{tabular}{|c|c|c|}
\hline Time Period & Average Annual Rate & Total Numbers \\
\hline $1960-1974$ & 1800 & 27000 \\
\hline $1975-1984$ & 4000 & 40000 \\
\hline $1985-1989$ & 12000 & 60000 \\
\hline Since 1990 & 20000 & - \\
\hline
\end{tabular}

Africa has been highly impacted with the outward mobility of highly skilled labour, though this is not a new challenge. In support of this argument, there is an enormous negative experience of brain drain in Africa with an estimated forty percent of the Africa's top professionals living abroad (Benedict and Ukpere 2012). According to the authors, the cost of this knowledge leakage to the continent is over US\$4 billion per year in consultancy and expatriation (Benedict and Ukpere 2012).

\section{MIGRATION AND MOBILITY IN THE SOUTHERN AFRICAN CONTEXT}

Intra-regional migration in Southern Africa is a well-known phenomenon and dates back to the mid-nineteenth century. As claimed by Crush, Williams and Peberdy (2005), the notion of migration impacted on the regional labour market during the twentieth century in the subcontinent as well.

Entrenched patterns of migration have undergone major restructuring over time and Southern Africa is now a region on the move. According to Crush et. al (2005), several broader changes underlie this shift towards greater and greater intra-regional mobility, and for the purpose of this article only two of these are highlighted as follows: 
"First, the end of apartheid, a system designed to control movement and exclude outsiders, produced new opportunities for internal and cross-border mobility and new incentives for moving. The ensuing integration of South Africa with the SADC region brought a major increase in legal and undocumented cross-border flows and new forms of mobility. Second, the region's reconnection with the global economy has opened it up to forms of migration commonly associated with globalization."

The integration of South Africa into the SADC and the deliberate policy choice by South Africa to embrace globalization have implications for the patterns of movements of people in and out of the country.

A United Nations Educational, Scientific and Cultural Organization (UNESCO) $(2012,7)$ report on "Southern African Development Community (SADC) students are most mobile students worldwide, with six out of every hundred higher education students studying abroad". However, the "disaggregated data show that indeed the proportion of SADC mobile students staying in their own region is as high as $50 \%$ - second only to Western Europe" (UNESCO 2012, 9). The UNESCO report further indicates South Africa mostly attracts students with "nearly one-half of all mobile students from SADC go to study in South Africa, followed by the United Kingdom (10\%), the United States (8\%), France (7\%) and Australia (6\%)" (UNESCO 2012, 9). As earlier claimed, this trend further supports the intra-regional migration in Southern Africa.

\section{EXPERIENCES OF FOREIGN ACADEMICS IN SOUTH AFRICA HIGHER EDUCATION INSTITUTIONS}

In South Africa, the radical change of government that accompanied the shift from the apartheid state to a democratic state signalled the advent of widespread changes in higher education (Department of Education (DoE) 1997a). According to Jansen (2002, 5), "there was a past to be resolved through the creation of a single, coordinated system of higher education without racialised inequalities". There was also the need to incorporate the South African higher education system within fast-changing, technology-driven and information-based economies described under the rubric of globalisation (Department of Arts Culture Science and Technology 1996; DoE 1997b). The embracing of globalization and its attended global economy required put a particular pressure on the higher education system of the country.

While government (see DoE 1997a) set out the goal of developing a competitive higher education system that could contribute to economic development in an increasingly globalised environment, it was also faced with the challenge of redressing the inequalities in higher education that were caused by apartheid. In this regard, the 2001 National Plan on Higher 
Education (NPHE) (DoE 2001) proposed as a strategy to increase the access of black and disabled students in especially in post graduate programmes. It further proposed strategies to change staff profiles in higher education in line with the increase in the proportion of black students. One of these included the active recruitment of academics from the rest of Africa, which would play an important short-term goal of providing role models for black students and in helping to change institutional cultures. It was believed that this would also contribute to the broader development of intellectual and research networks across the continent, and thus contributing to the social and economic development of African as a whole (DoE 2001). Thus, as part of the transformation of higher education, the recruitment of students and academics from the rest of the African continent was identified as one of the key strategies.

At the turn of this century, South Africa also positioned itself to strengthen its science and technology expertise and capacity and to become a preferred destination for technology transfer. Part of the strategy to achieve this would be to tap into foreign skills base as well as building strategic cooperation and collaboration through a range of international and regional forums (SADC 1997). It is in the context of these developments around South Africa's need for trained personnel especially in the areas of critical scare skills that this article will now shift its analysis to the mobility of scholars in South Africa. In order to facilitate this mobility, South Africa passed the Immigration Amendment Act, 2004 (Act 19 of 2004), which was aimed at attracting scares skills required by the economy in accordance with vision 2014 of eradicating poverty and underdevelopment (The Presidency (Republic of South Africa) 2004). The policy further acknowledges the need for employment of foreign labour to boost economic growth. In this regard, it proposes the facilitation of foreign investment, enabling the entry of exceptionally skilled or qualified people, increase the number of skilled resources and facilitates academic exchange programmes (Government Communication and Information System (GCIS) 2004/5).

Despite its commitment to recruitment of foreign labour there are some protectionist provisions in the Act whereby it is stated that the contribution of foreigners to the South African labour market should be facilitated provided it does not adversely impact on the existing labour standards and the rights and expectations of South African workers. It further advocates for the maintenance of a policy connection between foreigners working in South Africa and the training of South African citizens. In practice, foreign skills or workers should only be employed or recruited if there can be evidence provided that there are no qualified nationals to do the job. In the application of this policy, some foreign academics have complained about the challenges they experience in applying for and obtaining work permits. In the survey that was conducted, one of the respondents explained his frustrations as follows: 
"The process of getting the permits is a nightmare. The amount of documents needed by the Home Affairs Department is numerous .... With regard to work permit, I got a job offer letter from the University after being interviewed for the job. The interview process was fine but the Home Affairs wanted additional motivation for offering the job opportunity to a non-South African, which the University was able to give." (R8, U3, 2).

The question that needs to be posed is, how does South Africa's foreign policy and international relations, find expression in international academic staff mobility?

\section{TREND ANALYSIS OF SECONDARY DATA OF ACADEMIC MOBILITY IN SOUTH AFRICA PUBLIC UNIVERSITIES}

Table 2 presents the headcount of permanent instruction and research staff in South African public universities by regions for selected year (2000, 2005 and 2010). Seven regions from the HEMIS were identified as Asia, Australia and Oceania, Europe, North America, South America, SADC, Rest of Africa and South Africa. Countries accounted for in the SADC region category are: Angola, Botswana, Democratic Republic of Congo (DRC), Lesotho, Malawi, Mozambique, Namibia, Swaziland, Tanzania, Zambia, Zimbabwe, Mauritius and Seychelles.

Table 2: Headcount of permanent instruction and research staff in South African public universities by regions for selected year (2000, 2005 and 2010): (Asia, Australia and Oceania, Europe, North America, South America, SADC South Africa and the Rest of Africa)

\begin{tabular}{|c|c|c|c|c|c|c|c|c|c|}
\hline $\begin{array}{c}\text { Yearl } \\
\text { Region }\end{array}$ & Asia & $\begin{array}{c}\text { Australia \& } \\
\text { Oceania }\end{array}$ & Europe & $\begin{array}{c}\text { North } \\
\text { America }\end{array}$ & $\begin{array}{c}\text { South } \\
\text { America }\end{array}$ & SADC & $\begin{array}{c}\text { South } \\
\text { Africa }\end{array}$ & $\begin{array}{c}\text { Rest of } \\
\text { Africa }\end{array}$ & $\begin{array}{c}\text { No } \\
\text { Info }\end{array}$ \\
\hline 2000 & 95 & 19 & 409 & 81 & 18 & 96 & 13099 & 148 & 667 \\
\hline 2005 & 33 & 12 & 229 & 47 & 6 & 196 & 14178 & 168 & 433 \\
\hline 2010 & 87 & 19 & 369 & 75 & 11 & 482 & 15194 & 319 & 128 \\
\hline
\end{tabular}

Table 2 shows that South Africa drew international academic staff from all the regions of the world. It further shows that the majority were drawn from the African continent and followed by Europe. The dominance of African and Europe should be understood in the light of the historical ties South African has with the African continent and Europe. There has been observable decline in the number of internal academic staff between 2000 and 2005 which was followed by an increase between 2005 and 2010. The reasons for this decline are unknown and they require further research.

Graph 1 shows that there were more male than female international academic staff in South Africa higher education. This is the opposite of student enrolments where female students were more than male students. 
Graph 1: Headcount of permanent instruction and research staff in South African public universities according to gender and regions (2000, 2005 and 2010)

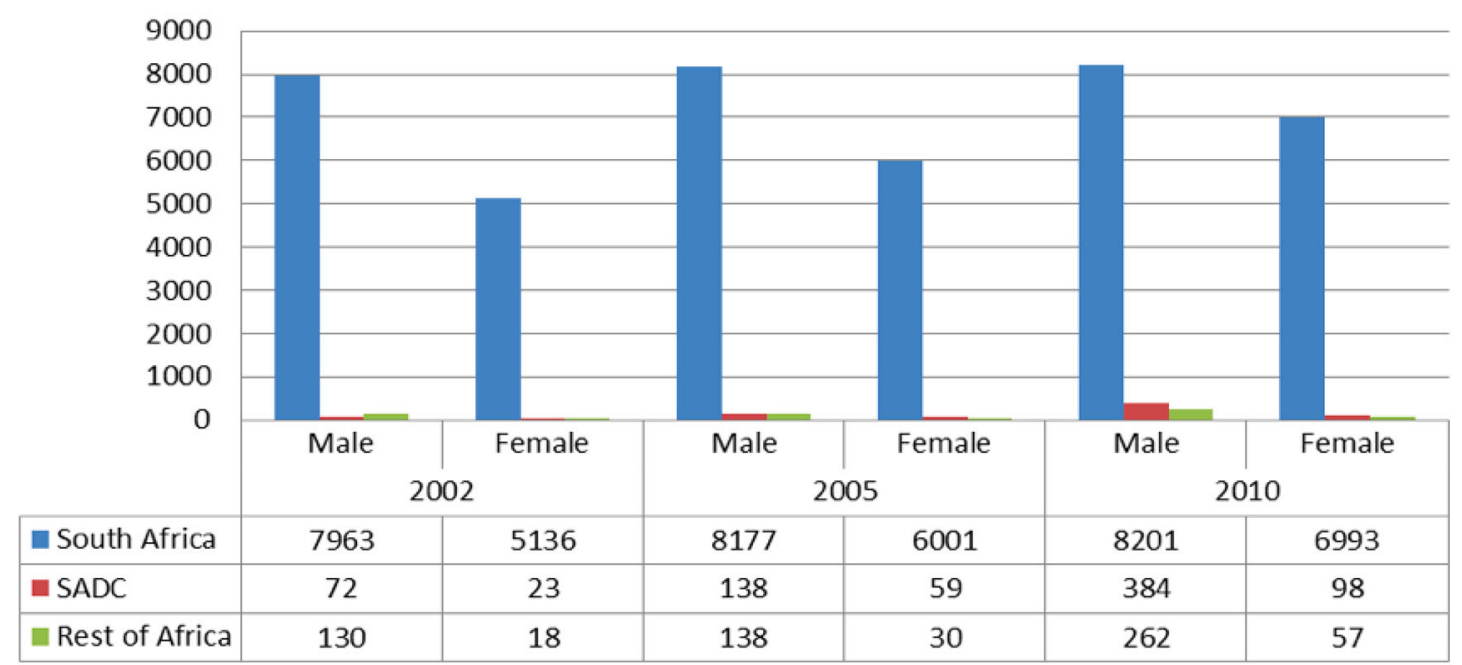

\section{PULL AND PUSH FACTORS THAT INFLUENCE ACADEMIC MOBILITY IN SOUTH AFRICA}

This section analyses the data from the questionnaire of selected African academics in South African public universities. An analysis of the staff questionnaire shows more similarities than differences between what happened elsewhere and also what happened in South Africa pertaining to the phenomena of migration and mobility of academics. This section describes the data from the questionnaires by emphasising the similarities with the whole continent and globe, and also highlighting the differences.

\section{REASONS THE ACADEMICS GIVE FOR CHOOSING TO COME, AND ALSO TO WORK IN SOUTH AFRICA}

There are different reasons why academics choose South Africa as their destination for academic mobility. These include their desire to contribute to knowledge generation; their quest for learning and development as professionals and in their research profiles, South Africa being viewed as a better platform for educational innovation compared to other African countries. South Africa also offered options for pursuit of one's country career paths than the home country as demonstrated in the following input from one of the respondents:

"In my country arts education is none existent in schools. It is only recently that rudimentary introduction of what is called Creative and Performing Arts are being introduced in schools. For me it was very frustrating to work in an environment where my skills were not valued. Because arts education is recognised in South Africa, I felt that coming here would provide me with work 
experience and give me an opportunity to share what I have learned." (R4, U2, 2).

There is also some evidence of the link between international student mobility and recruitment of skilled labor as some respondents came South Africa as students and ended being recruited to become academics.

"I came to SA purely to study, but after my masters, I saw that the need for teaching mathematics is more dire in SA than in my country of origin, and so, decided to stay to make a contribution." (R3, U2, 2).

This supports Okereke's (2012) claim that most students who travel out of their countries to study, do not go back to their country of birth, implying therefore that mobile students are a fertile ground for the recruitment of foreign labour and expertise once they complete their studies.

There is also a link between where some of responded studied and ended working. One academic responded as follows as to why he chose to work at that institution:

"I just happened to have studied here and when there was an opening, I applied for a job. It was pure contingency." (R 2, U2, 2).

"Because I am also completing my studies here, I cannot be elsewhere." (R4, U1, 2).

Just like other studies have demonstrated, proximity to home was cited as one of the reasons for choosing to work in South Africa. "South Africa is closer to my home country" (R8, U2, 2).

\section{REASONS FOR WORKING IN SPECIFIC INSTITUTIONS}

Most academics work at institutions where they studied. Just like Okereke's claim, it can also be asserted that most students who travel out of their countries to study, do not go back to their country of birth (Okereke 2012), implying therefore that mobile students are a fertile ground for the recruitment of foreign labour and expertise once they complete their studies.

"I just happened to have studied here and when there was an opening, I applied for a job. It was pure contingency.” (R 2, U2, 2).

"Because I am also completing my studies here, I cannot be elsewhere." (R4, U1, 2)

While some had always wanted to come to South Africa and looked for jobs in institutions and then applied where there were advertisements in their fields:

"This is where there was a job offer in my field." (R6, U1, 2). 
"In my search South Africa was my target and this institution was the first to have a relevant opening for me." (R4, U2, 2).

Reputational issues also play a role in the choice of a particular institution, one of the respondents pointed out: "because of the institution's reputation. Being one of the top Universities in South Africa". (R7, U3, 2).

And another interesting reason given was the fact the, "institution had least students' disruptions and a wide range of resources". (R7, U3, 2).

\section{THE PROCESS OF GETTING INTO SOUTH AFRICA (JOB APPLICATION, THE INTERVIEW PROCESS AND OBTAINING WORK PERMITS)}

The experiences vary from not being a hassle for some, especially for those whose paper work was done by the institutions and not themselves to those who experienced many problems.

"The application process was straight forward, online Skype interview was most convenient, Work permit was facilitated by the institution and became a simple process." (R4, U2, 2).

"I only needed a study permit when I got into SA for the first time. For the work permit, the university assisted in obtaining the permit through an agent. It was stress free.” (R2, U2, 2).

For some respondents; dealing with the institutions was easy but dealing with Home Affairs was a night mare as some of the respondents witnessed.

"The job application and interview process was smooth but the work permit side is nothing to write home about." (R3, U2: 2)

For other academics it was very difficult to get the papers. For some academics the treatment at home affairs was the worst and one had the following to say:

"It is quite a challenge and also frustrating on the main and disheartening. The whole process is based on xenophobic tendencies which are highly discriminatory. It is in fact discouraging to go for an interview in South Africa with gatekeepers already on the wait for foreigners who seek to 'take jobs meant for our children'. The spirit is just negative despite the qualifications, expertise and the rare skills one can offer the country." (R1, U2, 2).

The other one supports this fact by saying:

"The challenge for me was getting a work permit. It took a very long time after my acceptance of the job offer to get a work permit. The process was long and tedious. Staff at Home Affairs was unfriendly and they seemed not to know what they were doing. I was told different and sometimes very conflicting messages. One staff member said the permit would take from 6 months up to 2 
years. I appealed to the then Head of School who contacted Home affairs directly. After her intervention my permit was ready the next day." $(\mathrm{R} 1, \mathrm{U} 2,2)$.

One cannot help it but include the third statement from another academic in order to emphasise the fact which is:

"This aspect has been my main area of frustration. I have been on study permit for years followed by work permit. The process of getting the permits is a nightmare. The amount of documents needed by the Home Affairs Department is numerous. At first I was to apply yearly for extension then it changed to cover the duration of the study which was two to four years depending on the course taken. With regard to work permit, I got a job offer letter from the University after being interviewed for the job. The interview process was fine but the Home Affairs wanted additional motivation of offering the job opportunity to non South Africa which the University was able to give." (R3, U2, 2).

Looking at the comments made by these academics, one can conclude that in the South African institutions, international academic staff seems to be happy with institutional processes for recruitment and appointment. On the contrary, the process of getting work permit was found to be not supportive. This works against South Africa's quest to recruit skilled labour from outside the country. This matter requires urgent attention if some Africa is to become a serious player in recruitment of talent in the global economy.

\section{UPWARD MOBILITY IN INSTITUTIONS}

The research also tried to establish the kind of opportunities available for upward mobility and career path development for international academic staff. These varied from negative experiences to positive ones. The negative experiences related to alleged racism and xenophobia as demonstrated by the following responses:

"Ever since I came to this institution I have not taught a single course except to tutor in courses taught by others. In some instances I have to tutor courses taught by first degree holders, although I have experience in teaching courses to Masters Students elsewhere successfully. This is coupled with the fact that in other cases I have distinctions in those courses. Despite a wide range of journal article publications, the institution still keeps me at the lowest rank of academic staff." (R3, U2, 2)

\section{KNOWLEDGE ABOUT DEPARTMENT, INSTITUTION OR COUNTRY KNOWN NOW, THAT WAS NOT KNOWN BEFORE}

This section is divided into positive and negative responses. The first responses would be from those academics whose expectations were not met and ended being disappointed. Some academics expressed the views that that South African institutions are "riddled with the same 
squabbles that are there in other African institutions and countries" Some say that they did not know that there was racism and xenophobia in a country that purports have attained independence and has been a "democracy" for 18 years. One of them sadly reports that

"Priority goes to a white person to occupy a position of authority and any succession is based on the race factor. I then question the principle and ask myself: where is the black empowerment? Then I become even more disappointed when even the South African black citizens are the first to embrace the racial set-up left by apartheid! To me this is unexpected especially in education studies departments where there should be practical thinkers in philosophy, psychology and sociology." $(\mathrm{R} 1, \mathrm{U} 2,2)$

The fact that the institutions are still very black and white was amazing for many respondents. Some academics feel that the education system still perpetuate marginalization of disadvantaged groups because the systems in place still favor the advantaged children while many of the ordinary children in many walks of life cannot access some services still. In some institutions, there appears to be dominant discourses within departments where there is recognition of certain forms of knowledge and knowledge systems and undermining others. These academics feel that they sometimes find themselves caged or operating from the margins within those specific departments while they could add more value with indigenous knowledge forms "It is either you know Shakespeare or you are stupid" (R5, U1, 2).

There are some positive issues raised as well. Some academics raised the fact that "South Africa as a country is really advanced in many ways compared with other African countries" (R7, U3, 2).

On the issue of what the academics could have done differently, knowing what they know now; respondents expressed feelings of despair and desperation especially as result of experiences from Home Affairs. "I am not sure there is much one can do. As an outsider you just have to subject yourself to all the abuse just so you can get your papers and be in South Africa legally" (R5, U1, 2).

They were asked to come up with solutions to the challenges that they thought South Africa had and also advice the other new academics who would want to come to South Africa in future. They mentioned the following:

"First I would propose equality of recognition to be done using experience, expertise and qualifications of the incumbent." (R1, U2, 2).

"Firstly, I would develop a home grown philosophy of education that can guide the country and address the needs of all South Africans. I would provide training of trainers' course to unemployed youth and have them man school counselors' posts, thus create employment and relieve teachers to teach instead of worrying about psychosocial problems of learner." (R8, U3, 2). 
The positive responses were that "the diversity of the institutions in terms of staff, students and research orientations is an asset for those who have a vision to grow in their career" (R7, U3, 2) while the other one said "What I now know and experienced has contributed to my professional and personal growth. I have learnt” $(\mathrm{R} 8, \mathrm{U} 3,2)$.

\section{CONCLUSION}

This article has highlighted the patterns of international academic mobility in a global context, showing that it was driven by pull and push factors. International academic staff has been used in different nation states and at different times for capacity building. This was particularly the case in Japan overseas British, Spanish and French colonies. Push factors such as xenophobia and repressive regimes have contributed to outward mobility of international and national faculty as it was the case in Germany, Japan and some African countries. In some cases this has led to brain drain that has come at cost especially to many African countries. The article has also demonstrated how South Africa is attracting international academic staff to its higher education system. This academic contributes to address shortage of skills especially in areas of critical scares skills. As part of the transformation of higher education, the South African government identified the recruitment of post graduate students as well as qualified faculty from the African continent. This has contributed to the increase of international academic staff from the African continent. This study has further shown that some protectionist measures in the immigration policies of South Africa are serving as an impediment to access of international academic staff to the South African labor market. If South Africa is to be a significant player in tapping into the global skills labor market, it would have to improve its immigration policies to facilitate easy access to work permit to skilled labor interested in working in South Africa. For the international academic staff working in South Africa, it was demonstrated that they have both positive and negative experiences. The negative experiences seem to be related to the major nation building project to overcome racism and xenophobia. The principles of nonracialism and, non-discrimination need to be promoted in order to build an inclusive and socially coherent society.

\section{REFERENCES}

Altbach, P. G. 1989. The new internationalism: Foreign students and scholars. Studies in Higher Education 14(2): 125-136.

Agarwal, P., M. Said, M. Sehoole, M. Sirozi and H. de Wit. 2007. The dynamics of international student circulation in a global context. In Higher education in the new century: Global challenges and innovative ideas: 109-144. 
Balibar, E. 1992. Is there a 'neo-racism'? In Race, nation, class: ambiguous identities, ed. E. Balibar and I. Wallerstein, 17-28. New York, Verso.

Barjak, F. 2005. Doctoral students in the life sciences. Paper prepared for the NetReAct Project he role of networking in research activities. E. GmbH. Switzerland University of Applied Sciences Solothurn Northwestern Switzerland.

Benedict, O. H. and W. I. Ukpere. 2012. Brain drain and African development: Any possible gain from the drain? African Journal of Business Management 6(7): 2421-2428.

Butcher, N., M. Wilson-Strydom, S. Hoosen, C. MacDonald, A. Moore and L. Barnes. 2008. A profile of higher education in the region. Towards a common future: Higher education in the SADC region. Research Findings from four SARUA Studies. P. Kotecha. Johannesburg, South Africa Southern African Regional Universities Association (SARUA).

Cantwell, B., S. G. Luca and J. J. Lee. 2009. Exploring the orientations of international students in Mexico: Differences by region of origin. Higher Education 57(3), 335-354.

Crush, J., V. Williams and S. Peberdy. 2005. Migration in Southern Africa. Policy analysis and research programme of the Global Commission on International Migration, Cape Town.

Department of Arts Culture Science and Technology. 1996. White Paper on Science and Technology: Preparing for the 21st Century.

Department of Education. 1997a. A programme for the Transformation of Higher Education (Education Draft White Paper 3).

Department of Education. 1997b. Higher Education Act 101 of 1997.

Department of Education. 2001. National Plan on Higher Education Department of Education.

DoE see Department of Education.

Franzoni, C., G. Scellato and P. Stephan. 2012. Foreign born scientists: Mobility patterns for sixteen countries. National Bureau of Economic Research.

GCIS see Government Communication and Information System.

Government Communication and Information System. 2004/5. South African Yearbook 2004/5. GCIS.

Hervik, P. 2004. Anthropological perspectives on the new racism in Europe, Ethnos, 69, 140-155.

Heggins, W.J. and Jackson, J.F., 2003. Understanding the collegiate experience for Asian international students at a Midwestern research university. College Student Journal, 37(3), pp.379-392.

Institute of International Education. 2011. What international students think about U.S. higher education: Attitudes and perceptions of prospective students in Africa, Asia, Europe and Latin America. Open Doors. P. Chow, Institute of International Education.

Ishengoma, J. M. (Ed.). 2008. Country case studies: Tanzania. In Higher education in Africa: The international dimension. Boston and Accra: Center for International Higher Education, Boston College and the Association of African Universities, Association of African Universities (AAU).

Jansen, J. D. 2002. Mergers in higher education: Lessons learned in transitional contexts. Unisa Press.

Kondakci, Y., 2011. Student mobility reviewed: Attraction and satisfaction of international students in Turkey. Higher Education, 62(5), p.573.

Kim, T. 2009. Shifting patterns of transnational academic mobility: A comparative and historical approach. Comparative Education 45(3): 387-403.

Lee, J. J. and B. Cantwell. 2012. The global sorting machine: An examination of neoracism among international students and postdoctoral researchers. In Universities and the Public Sphere, 61-78). Routledge.

Lee, J. J. and C. Rice. 2007. Welcome to America? International student perceptions of discrimination. Higher Education 53(3): 381-409.

Lee, J. and T. Opio. 2011. Coming to America: Challenges and difficulties faced by African student athletes. Sport, Education and Society 16(5): 629-644. 
MacGregor, K. 2007. "SOUTH AFRICA: Huge growth in foreign students." http://www.university worldnews.com/article.php?story=20071206163532421

Mario, M., P. Fry, L. A. Levey and A. Chilundo. 2003. Higher education in Mozambique. Oxford: James Currey; Maputo: Imprensa and Livraria Universitaria Universidade Eduardo Mondlane.

Marginson, S., C. Nyland, E. Sawir and H. Forbes-Mewett. 2010. International student security. Cambridge University Press.

Martin, S. 2004. "Women and migration." Documento presentado en la Reunión consultiva sobre migración y movilidad y sus efectos sobre las mujeres, Naciones Unidas, Malmo 2.

Meyer, J. B. and D. Bernal. 1996. Brain gain strategy for South Africa. Pretoria, South Africa: Foundation for Research Development.

National Science Board. 2012. Science and Engineering Indicators 2012. Science and Engineering Indicators Digest. National Science Board.

Okereke, C. 2012. 14 June 2012. Universities must be urgently mended and brain drain stemmed. http://www.universityworldnews.com/article.php?story $=20120529151744768$

OECD see Organisation for Economic Co-operation and Development.

Pritchard, R. M. and B. Skinner. 2002. Cross-cultural partnerships between home and international students. Journal of Studies in International Education 6(4):323-353.

SADC see Southern African Development Community.

Samoff, J. and B. Carrol. 2004. The promise of partnership and continuities of dependence: External support to higher education in Africa. African Studies Review: 67-199.

Sawir, E., S. Marginson, A. Deumert, C. Nyland and G. Ramia. 2008. Loneliness and international students: An Australian study. Journal of studies in international education 12(2): 148-180.

Sehoole, C. (Ed.). 2008. Issues, policies, and developments of internationalization in Africa: Comparative analysis. Higher education in Africa: The international dimension. Boston and Accra: Center for International Higher Education, Boston College and the Association of African Universities, Association of African Universities (AAU).

Sehoole, C. T. 2011. Student mobility and doctoral education in South Africa. Perspectives in Education 29: 3 .

Southern African Development Community. 1997. Protocol on Education and Training (SADC). http://www.unisa.ac.za/contents/projects/docs/SADC\%20PROTOCOL\%20ON\%20EDUCATIO N\%20\%20AND\%20TRAINING.pdf (Accessed 15 November 2008).

The Presidency (Republic of South Africa). 2004. Immigration Amendment Act, 2004. (Act 19 of 2004). H. Affairs. Cape Town

UNESCO see United Nations Educational Scientific and Cultural Organization.

United Nations Educational Scientific and Cultural Organization. 2012. New Patterns in Student Mobility in the Southern Africa Development Community. UIS Information Bulletin. United Nations Educational, Scientific and Cultural Organization, 7.

Zeleza, T. 2003. Rethinking Africa’s "globalization". Africa World Press. 